\title{
Drivers and barriers to sustainable fisheries in two peri-urban impoundments in Zimbabwe
}

\author{
Beaven Utete ${ }^{1,3 *}$, Crispen Phiri ${ }^{2}$ and Tosan B Fregene ${ }^{3}$ \\ 'Department of Wildlife Ecology and Conservation, Chinhoyi University of Technology, Chinhoyi, Zimbabwe \\ 2Department of Freshwater and Fishery Science, Chinhoyi University of Technology, Chinhoyi, Zimbabwe \\ ${ }^{3}$ Department of Aquaculture and Fisheries Management, University of Ibadan, Oyo State, Nigeria
}

\begin{abstract}
Fisheries sustainability is categorised through four conceptual pillars: ecological, economic, and social, including cultural and institutional. Much work on fisheries sustainability has been done in marine fisheries relative to inland fisheries. Two inland peri-urban impoundments, Chivero and Manyame in Zimbabwe, support numerous small-scale fisheries; however, environmental and socioeconomic variables threaten the sustainability of the fisheries. This study aimed to identify and contextualise drivers and barriers to sustainability of small-scale fisheries in these two peri-urban impoundments. We applied three frameworks, Fishery Performance Indicators, Community-Based Fishery Indicators and FAO Small-Scale Fisheries Indicators, to identify and contextualise the drivers and barriers. Quantitative and qualitative methods were used to collect data from fishers in the two impoundments. A structured questionnaire was administered to 115 fishers in 23 fishing companies operating in the two lakes. Fisheries income and revenue as well as food security are key drivers. Lack of postharvest equipment, volatile fish markets, water quality and quantity deterioration and fish stock decreases are key barriers to sustainability of fisheries in the two impoundments. There are subtle differences in the extent and impact of the drivers and barriers of fisheries sustainability in the two lakes. The differences relate to the uniqueness of the aquatic habitats, social constructs and fisheries operational frameworks in each lake. This suggests a need to assess fisheries sustainability using an integrated bottom-up approach starting from individual fisheries $<$ community fisheries $<$ global/generic fisheries.
\end{abstract}

Keywords: peri-urban fisheries, food security, water resource conservation, water pollution, sustainability

\section{INTRODUCTION}

Small-scale inland fisheries provide essential ecosystem services comprising food, nutrient cycling in water, employment and income to millions of people, and generate foreign currency for developing countries such as Zimbabwe in Sub-Saharan Africa (Allison et al., 2009; Marshall, 2011; FAO, 2013, 2014a,b,c, 2016; Bartley et al., 2015). Inland fisheries support numerous livelihoods and enhance the socioeconomic development of urban and rural areas in Africa (Allan, 2005; WorldFish, 2009; AU-IBAR, 2012; De Graaf and Garibaldi, 2014). However, the sustainability of inland fisheries is threatened by a plethora of factors, including aquatic environmental degradation (Welcomme et al., 2009; Cooke et al., 2012), overexploitation and overfishing (FAO, 2015 ; 2016) and market volatility of fish prices (Taylor et al., 2007; Vörösmarty et al., 2010). The dynamics in other factors such as geographical expansion, fishing capacity-building, natural variability and climate change further threaten the viability of inland fisheries (Béné, 2003; Allison and Horemans, 2006; Garcia and Rosenberg, 2010). Hence it is imperative to effectively monitor and assess the state of freshwater inland fisheries (FAO, 2016).

Within Africa, contemporary fisheries assessment and management remain heavily dominated by the ecological aspects and to a lesser extent the economic aspects (Stephenson et al., 2018). No comprehensive and holistic frameworks exist to integrate and evaluate various other aspects such as the cultural, political, institutional and social elements threatening the sustainability of small-scale inland capture fisheries (Bond

*Corresponding author, email: mkaiyo@gmail.com

Received 9 August 2018; accepted in revised form 26 September 2019 and Morrison-Saunders, 2011; FAO, 2016; Thompson and Stephenson, 2016). The challenge in evaluating the sustainability of fisheries is largely driven by a lack of reliable and consistent fisheries statistics (Cooke et al., 2013), and non-cogent classification of small-scale fisheries into urban, rural and periurban sets, and this tends to complicate effective management of small-scale inland fisheries (Béné et al., 2003; Kebe and Tallec, 2006; FAO, 2010; Bartley et al., 2015). As a result of lack of a clear assessment framework for sustainability and reliable statistics, small-scale inland fisheries are excluded from national and regional economic planning initiatives and are notably absent in the Sustainable Development Goals (Bartley et al., 2015, FAO, 2015; Link et al., 2017; Stephenson et al., 2018). Clearly, there is a need for a framework that assesses the ecological, economic, institutional and social elements or indicators of fisheries to evaluate their sustainability (Stephenson et al., 2018).

Two contiguous peri-urban eutrophic lakes, Chivero and Manyame, in Zimbabwe support numerous fisheries and provide vital ecosystems services such as potable water and habitat for aquatic organisms (Marshall, 2011). The viability and sustainability of the fisheries in the two impoundments is threatened by a number of factors such as water pollution, climate change, over-abstraction of the water and competing water withdrawing activities (Magadza, 2011; Mhlanga and Mhlanga, 2013). Despite their ecological and socioeconomic significance, fisheries in urban and peri-urban impoundments such as Chivero and Manyame are not often a national priority and are undervalued and largely overlooked in Zimbabwe (FAO, 2015; Kupaza et al., 2015). This study aimed to identify and contextualise drivers and barriers to sustainability of small-scale fisheries in these two peri-urban impoundments. Three indicators - Fishery Performance Indicators (FPI) described by Anderson et al. (2015), Community-Based Fishery 
Table 1. Frameworks for indicators of drivers and threats to sustainability of small-scale inland fisheries in Lakes Chivero and Manyame, Zimbabwe for 2017

\begin{tabular}{|c|c|c|c|}
\hline Framework & Reference & Target audience & Intended application \\
\hline Fishery Performance Indicators & Anderson et al. (2015) & Individual-level fisheries & $\begin{array}{l}\text { Rapid sustainability assessment of } \\
\text { individual fisheries }\end{array}$ \\
\hline $\begin{array}{l}\text { Community-Based Fishery } \\
\text { Indicators }\end{array}$ & Boyd and Charles (2006) & Individual fishing communities & $\begin{array}{l}\text { Develop and monitor a set of } \\
\text { local-level community relevant } \\
\text { sustainable development } \\
\text { indicators }\end{array}$ \\
\hline $\begin{array}{l}\text { FAO Small-Scale Fisheries } \\
\text { Indicator }\end{array}$ & $\begin{array}{r}\text { Food and Agriculture } \\
\text { Organisation (2015) }\end{array}$ & Small-scale fisheries & $\begin{array}{l}\text { Develop capacity of small-scale } \\
\text { fisheries to improve food security } \\
\text { and reduce poverty }\end{array}$ \\
\hline
\end{tabular}

Indicators (CFI) following Boyd and Charles (2006) and FAO Small-Scale Fisheries Indicators (FSSFI) (FAO, 2015) - shown in Table 1, were used to evaluate the drivers and barriers threatening the sustainability of fisheries and viability of fishing livelihoods in Lakes Chivero and Manyame, Zimbabwe.

\section{MATERIAL AND METHODS}

\section{Study area}

Lakes Chivero and Manyame (Fig. 1) are two peri-urban impoundments located about $30-40 \mathrm{~km}$ south-east of Harare, the capital city of Zimbabwe (Magadza, 2003). Morphometrically, Lake Chivero has a capacity of 247181 $\times 10^{6} \mathrm{~m}^{3}$, a mean depth of $9.4 \mathrm{~m}$ and a surface area of 2630 ha with a retention time of 1.1 years. Lake Manyame has a surface area of 8100 ha at full capacity, when its maximum and mean depths are $23 \mathrm{~m}$ and $5.6 \mathrm{~m}$, respectively, with an estimated mean retention time of 0.7 years (Marshall, 2011; Utete et al., 2018). The impoundments were constructed in 1952 and 1976, respectively, to mainly provide potable water to Harare (then Salisbury City). However, other uses such as water abstraction for irrigation, small-scale and subsistence fishing and recreational activities such as boating, angling and birdwatching have evolved over the years (Marshall, 2011).

With regard to small-scale fishing, there are a total of 23 fishing cooperatives (12 in Lake Chivero and 11 in Lake Manyame). Each fishing cooperative consists of at least 8-11 members who contribute fishing gear (boats and nets), labour and start-up capital, as well as paying the permit fees to National Parks (Utete et al., 2018). The fisheries from Lake Chivero have been estimated to catch an annual yield of $250 \mathrm{~kg} \cdot \mathrm{h}^{-1} \cdot \mathrm{yr}^{-1}$ fish (Marshall, 2011), though there is no clear estimate of catches in Lake Manyame (Utete et al., 2018). The allowed mesh sizes in the two lakes range from $26 \mathrm{~mm}$ to $152 \mathrm{~mm}(1-6$ ") with $12.5 \mathrm{~mm}(0.5$ ") increments (Marshall, 2011). Fish catches have been declining in the two lakes, thus threatening the sustainability of the fisheries and the livelihoods of the fishers (Utete et al., 2018). Hence there is a need for an integrated framework to assess the sustainability of the fisheries, not only from a stock assessment perspective but using a holistic lens approach encompassing other covariates such as water pollution, post-harvest considerations, market accessibility as well as demographic aspects (FAO, 2015).

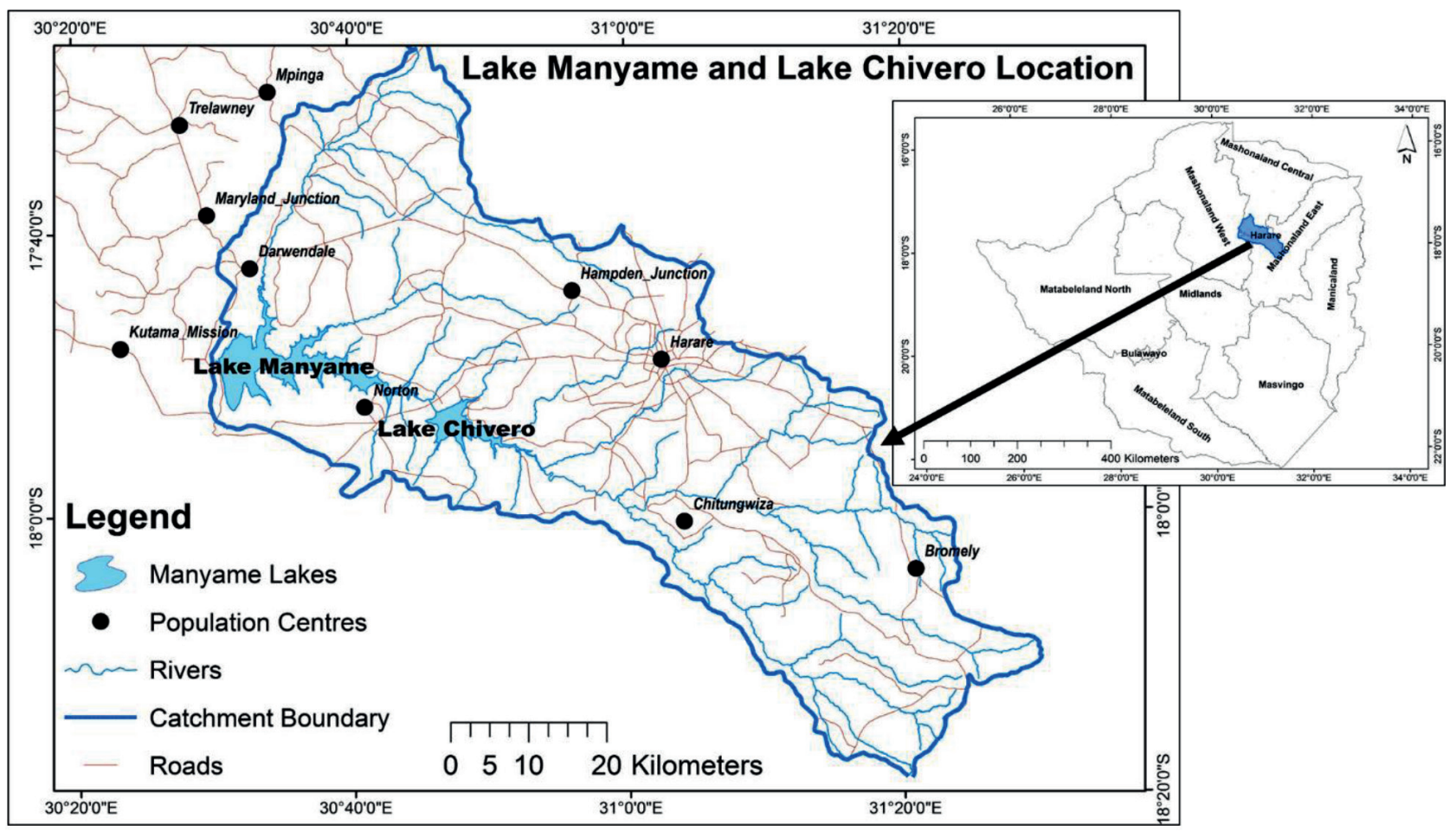

Figure 1. Location of the study area, Lakes Chivero and Manyame in Zimbabwe 


\section{Data collection}

We employed a mix of quantitative and qualitative methods to collect data from fishers in 2017. A structured questionnaire was administered to 115 fishers in 23 fishing cooperatives operating in Lakes Chivero and Manyame. Focus group discussions and key informant interviews were done on active men and women fishers, and Parks officials responsible for Lakes Chivero and Manyame, in order to have an in-depth qualitative cross-validation of the drivers and challenges affecting their livelihoods. From 115 questionnaires administered, 87 fully completed ones were used for further data analysis.

\section{Description of the indicator frameworks and their assessment in fisheries}

Three indicators, Fishery Performance Indicators (FPI) after Anderson et al. (2015), Community-Based Fishery Indicators (CFI) by Boyd and Charles (2006) and FAO SmallScale Fisheries Indicators (FSSFI) frameworks, summarised in Table 1, were used to evaluate the drivers and barriers threatening the sustainability of fisheries and viability of fishing livelihoods in Lakes Chivero and Manyame, Zimbabwe. Conceptually, separating measures of performance, the FPI uses 68 individual outcome metrics - coded on a 1 to 5 scale based on expert assessment to facilitate application to datapoor fisheries and sectors - that can be partitioned into sectorbased or triple-bottom-line sustainability-based interpretative indicators conveniently classified into ecology, economic, social and community aspects (Anderson et al., 2015). For any given fishery or cooperative, the respondents, who were mostly fishers, were asked a raft of closed and open-ended questions which are broadly classified into ecology, economic, social and institutional aspects. Every recurring theme or response is scored on a scale of 1 to 5 and the results are collated as a mean for each theme in the main classification scheme. The frequency of recurrence of any theme implies its significance as an aspect to measure the sustainability of the fishery (Chu et al., 2017).

The Community-Based Fishery Indicators (CFI) by Boyd and Charles (2006) presupposes a collection of fisheries in a water body to be a fishing community. Then it assesses a wide array of aspects ranging from the fishing fleets or vessels, nets, gender composition and roles, access to financial capital, fishery training facilities and opportunities afforded to the fishing community. It also assesses on a thematic basis the perceptions of the fishing community on fish stocks, depletion levels, and environmental issues such as water pollution and climate change (Boyd and Charles, 2006). Frequently recurring or generic issues across the fishing community are broadly categorised into ecological, social, economic and institutional categories (Boyd and Charles, 2006; FAO, 2015). The idea is not to weigh the significance of the factors but to get a holistic perspective from the fishing communities who are on the ground on the topical or recurring factors affecting their viability and livelihoods (FAO, 2015). This enables broad policy considerations rather than narrow quantified (weighed) aspects which tend to shift over temporal scales in fishing communities as the aquatic environment is largely dynamic (Bartley et al., 2015).

The FAO Small-Scale Fisheries Indicators (FSSFI) target mainly small-scale fishers who are considered as self-employed (FAO, 2013). The main factors considered are the food security and nutrition levels of the fishers, largely driven by fish stock dynamics, water quality concerns, climate change, changes in fishing regulations, fish poaching and competition for fishing zones (FAO, 2015). FSSI tends to evaluate the ecological elements of the fishing business on a Likert scale of 1-4 or 1-5, based on the mean responses or perceptions of the fishers themselves. In line with other fishery indicators, the most recurrent themes for any given fishery are allocated high scores 4 or 5 on the scale and are the key factors to be considered in fisheries management and ensuring and evaluating sustainability of small-scale inland fisheries (Stephenson et al., 2018).

\section{Comparative analysis of the perceptions of fishers}

After identification of the most recurrent factors influencing sustainability of small-scale fisheries in the two lakes using the three indicator frameworks, we further comparatively tested for the significance of differences in the perceptions of fishers in Lakes Chivero and Manyame towards the types of drivers and barriers affecting their livelihoods. For clarity, the mean perceptions are derived from the Likert Scale of: $1=$ strongly disagree, 2 = disagree, 3 = agree, and $4=$ strongly agree. Fishers in the two lakes were used as the test groups. After testing for normality using the Kolmogorov-Smirnov test, the data were found to be non-parametric, and thus we used descriptive and multivariate inferential statistics. We treated the two lakes as categorical groups, and since our perceptions were on a Likert scale of 1-4 we applied the 2-way contingency Chi square $\left(\chi^{2}\right)$ test of homogeneity for comparison at the 5\% level using the SPSS 21 version. The same test was also used to assess for differences in the livelihood strategies of the respondents between the two lakes.

\section{RESULTS}

\section{Demography and livelihood strategies of fishers in the two impoundments}

The basic demography of the fisheries in Lakes Chivero $($ males $=34$, females $=1)$ and Manyame $($ males $=45$, female $=7$ ) was skewed towards males. The majority $(n=13 ; 37 \%)$ of the fishers were primarily involved in fishing and farming, and the rest $(n=8 ; 23 \%)$ were fish traders in Lake Chivero (Table 2). In Lake Manyame, the majority ( $n=32 ; 62 \%)$ of the fishers were directly and actively involved in fishing, whereas a sizeable portion $(n=10 ; 19 \%)$ of the fishers were also into fish marketing and $10 \%(n=5)$ were engaged in trading and repairing of fishing gear such as nets and boats. The rest of the respondents $(n=5 ; 10 \%)$ were into farming as an alternative livelihood strategy in Lake Manyame (Table 2). Statistical analysis indicated a significant difference $\left(\chi^{2}(3)=14.749 ; p<\right.$ $0.05)$ in the actual livelihood strategies between the two lakes. For Lake Manyame, the hierarchy for the livelihood strategies was: fishing $>$ trading $>$ farming $>$ others, whilst for Lake Chivero it was: farming $>$ fishing $>$ trading $>$ others.

Table 2. Livelihoods of fishers in Lakes Chivero and Manyame. The percentage frequencies are in brackets.

\begin{tabular}{lcccll}
\hline \multirow{2}{*}{ Lake } & \multicolumn{4}{c}{ Occupation } & \multirow{2}{*}{ Total } \\
\cline { 2 - 5 } & Fishing & Farming & Trader & Other & \\
\hline Chivero & $13(37.1)$ & $14(40)$ & $8(22.9)$ & $0(0)$ & 35 \\
Manyame & $32(61.5)$ & $5(9.6)$ & $10(19.2)$ & $5(9.6)$ & 52 \\
Total & $45(51.7)$ & $19(21.8)$ & $18(20.7)$ & $5(5.7)$ & 87 \\
\hline
\end{tabular}




\section{Drivers and barriers of fisheries sustainability in Lakes Chivero and Manyame based on the fisheries viability indicator frameworks}

From the three indicator frameworks applied for the Lakes Chivero and Manyame, the FPI framework identified ecological elements such as depleting fish catches/stocks, deteriorating water quality, dynamic land-use patterns and climate change as barriers threatening the sustainability of the fisheries. Economic barriers such as volatile markets, poor postharvest preservation infrastructure, expensive annual fishing permits and unskilled fish processing workers also threaten sustainability of small-scale fisheries in both lakes. Social factors such as rapid fisheries managerial and casual labour turnovers, as well as lack of cross linkages with communities and unguaranteed short-term fisheries careers, act as barriers to the viability and sustainability of fisheries in the two lakes. Institutional or governance issues such as inaccessible fishing and harvesting rights are barriers to the sustainability of fisheries and livelihoods of fishers in Lakes Chivero and Manyame in Zimbabwe. Lack of collective bargaining action, for instance towards accessing loans and capital to maintain fisheries viability, is a barrier to sustainability of the fisheries. Inadequate participation of the community and exclusion of females in fisheries governance is a barrier to the sustainability of fisheries in the two lakes as indicated by the FPI (Table 3).

The CFI framework identified reductions in fish biodiversity, deterioration in the quality of lake habitat, decreases in fishable areas and drawdown zones as well as reductions in the catch of targeted species and an increase in by-catch wastes as ecological barriers to the sustainability of fishing communities in Lakes Chivero and Manyame. Fluctuations in the income value of fish harvests/catches, low market incentives for fisheries and fish which tend to be seasonal, as well as the low credit worthiness and natural capital are economic barriers to fishing-dependent communities in both lakes (Table 3). Dynamics in the demographic structure of fishing communities as well as access to fishing-related education and contribution and cooperation of marginal groups such as females and youths are some of the social factors affecting the two fishing communities (Table 3). Lack of an integrated approach towards research and management of fisheries resources are barriers towards sustainability of fishing communities (Table 3).

Using the FSSFI framework, aquatic habitat pollution and degradation are the main ecological barriers for sustainability of fisheries in the two lakes (Table 3). Volatile income from fish sales is the main economic barrier for sustainability of the small-scale fisheries in Lakes Chivero and Manyame (Table 3). Failure to uphold or respect cultures and ensuring gender equality and equity are social barriers for sustainable smallscale fisheries in the FSSFI framework (Table 2). Within the governance and institutional elements, lack of transparency of fisheries management, effective implementation of fishing rules and unclear access regulations are key barriers for sustainable fisheries in Lakes Chivero and Manyame (Table 3).

An evaluative summary of the three fisheries indicators show that fisheries-related income, employment, level of education of the fishers, and guaranteed food security and nutrition from fisheries, as well as accessible fish markets, are the key drivers for the sustainability of small-scale inland fisheries in the two lakes. Other key driving factors for sustainable fisheries comprise the level of fishing technology, such as fishing gear, boats and suitable post-harvest facilities, available (Table 3 ).

\section{Demography and comparative analysis of perceptions of fishers in the two impoundments}

The basic demography of the fisheries in Lakes Chivero (males $=34$, females $=1$ ) and Manyame (males $=45$, female $=7$ ) was skewed towards males with a large proportion $91 \%(n=79)$ and the rest $9 \%(n=8)$ were females.

The drivers and barriers facing small-scale inland fisheries suggested by peri-urban fishers and as indicated by the three frameworks were added and the results are summarised in Table 4. Among the identified drivers in sustainability of fisheries there were significant differences $\left(\chi^{2}(3), p<0.05\right.$ in

Table 3. List of fisheries sustainability indicators and the ecological, economic, social and governance elements considered for fisheries in Lakes Chivero and Manyame, Zimbabwe

\begin{tabular}{|c|c|c|c|c|}
\hline Index & Ecological elements & Economical elements & Social elements & Governance elements \\
\hline $\begin{array}{l}\text { Fishery Performance } \\
\text { Indicators }\end{array}$ & $\begin{array}{l}\text { Fish stock } \\
\text { Sustainable fisheries } \\
\text { Water quality } \\
\text { Land use patterns } \\
\text { Climate change }\end{array}$ & $\begin{array}{l}\text { Markets } \\
\text { Infrastructure } \\
\text { Harvest } \\
\text { Post-harvest equipment } \\
\text { Permits } \\
\text { Processing workers }\end{array}$ & $\begin{array}{l}\text { Managerial returns } \\
\text { Labour returns } \\
\text { Community service } \\
\text { Local ownership } \\
\text { Local labour } \\
\text { Career }\end{array}$ & $\begin{array}{l}\text { Fishing access rights } \\
\text { Harvest rights } \\
\text { Collective action } \\
\text { Participation } \\
\text { Community } \\
\text { Gender }\end{array}$ \\
\hline $\begin{array}{l}\text { Community-Based } \\
\text { Fishery Indicators }\end{array}$ & $\begin{array}{l}\text { Fish biodiversity } \\
\text { Quality of habitat } \\
\text { Area of fished and } \\
\text { unfished areas } \\
\text { Target species } \\
\text { abundance } \\
\text { By-catch or resource } \\
\text { waste }\end{array}$ & $\begin{array}{l}\text { Harvest value } \\
\text { Income } \\
\text { Market incentives } \\
\text { Food security } \\
\text { Credit worth } \\
\text { Natural capital }\end{array}$ & $\begin{array}{l}\text { Demography } \\
\text { Access to knowledge/Education } \\
\text { Contribution of marginal } \\
\text { groups } \\
\text { Cooperation }\end{array}$ & $\begin{array}{l}\text { Integrated approach to } \\
\text { fisheries } \\
\text { Research } \\
\text { Management of fisheries } \\
\text { resources }\end{array}$ \\
\hline $\begin{array}{l}\text { FAO Small-Scale } \\
\text { Fisheries Indicators }\end{array}$ & $\begin{array}{l}\text { Environmental } \\
\text { sustainability }\end{array}$ & Economic sustainability & $\begin{array}{l}\text { Respect of cultures } \\
\text { Gender equality and equity } \\
\text { Non discrimination }\end{array}$ & $\begin{array}{l}\text { Transparency } \\
\text { Rules and laws } \\
\text { Regulations } \\
\text { Property rights } \\
\text { Capacity to manage } \\
\text { Consultation and participation }\end{array}$ \\
\hline
\end{tabular}


Table 4. Comparative analysis of the perceptions of fishers in the two lakes towards drivers and barriers in fisheries sustainability

\begin{tabular}{|c|c|c|c|}
\hline & $x^{2}$ & $\begin{array}{c}\text { Mean } \\
\text { perceptions }\end{array}$ & SD \\
\hline \multicolumn{4}{|l|}{ Drivers } \\
\hline Education & $0.005^{*}$ & 1.93 & 0.367 \\
\hline Income activities & $0.002^{*}$ & 1.35 & 1.321 \\
\hline Fish for food security & $0.005^{*}$ & 1.36 & 0.493 \\
\hline Market & 0.422 & 1.54 & 0.85 \\
\hline Training & 0.142 & 2.15 & 1.070 \\
\hline Technology & 0.546 & 1.80 & 0.791 \\
\hline Livestock owned & $0.031^{*}$ & 1.57 & 0.492 \\
\hline House owned in $10 \mathrm{~km}$ radius & 0.355 & 0.28 & 0.543 \\
\hline \multicolumn{4}{|l|}{ Barriers } \\
\hline Catches decline & 0.439 & 1.03 & 0.183 \\
\hline Bay accessibility & 0.007 & 2.31 & 1.043 \\
\hline Water quality & 0.079 & 1.79 & 0.407 \\
\hline Water quantity & 0.682 & 1.81 & 0.502 \\
\hline Climate change & 0.652 & 3.44 & 0.684 \\
\hline Gender disparity & 0.247 & 2.08 & 0.955 \\
\hline No networking & 0.504 & 2.36 & 1.017 \\
\hline Legal frameworks & $0.022^{*}$ & 2.78 & 0.972 \\
\hline Obsolete infrastructure & 0.576 & 1.80 & 0.793 \\
\hline Financial capital & 0.126 & 1.41 & 0.495 \\
\hline
\end{tabular}

${ }^{\star}$ Denotes significant difference

the educational levels towards fishing-related issues among fishers in Lakes Chivero and Manyame (Table 4). There is a significant difference $\left(\chi^{2}(3), p<0.05\right)$ in the importance of fish harvest incomes as a driver for fishing among fishers between the two lakes. There is a significant difference $\left(\chi^{2}(3), p<0.05\right)$ in the fishers' perceptions towards the benefit of fish catches and by-catch wastes for food security between the two lakes (Table 4). Fishers in both lakes do not differ $\left(\chi^{2}(3), p>0.05\right)$ in their perceptions towards the availability and dynamics of the fish market as a driver of sustainability of fisheries (Table 4$)$.

Fishers in Lakes Chivero and Manyame concur $\left(\chi^{2}(3)\right.$, $p>0.05)$ that declines in peri-urban fish stocks, reductions in water quality and quantity as well as climate change, gender disproportion, poor networking among fishers, and obsolete post-harvest equipment and infrastructure, as well as inaccessible and low financial capital, are the main barriers to sustainability of fisheries (Table 4). Most fishers in both lakes consider bay accessibility / fishing zone restrictions / prohibitions as barriers for their fishing business. However, fishers from both lakes differ significantly in their perceptions of the barrier role played by reduced fishing bay accessibility on fish catches $\left(\chi^{2}(3), p<0.05\right)$ and the lack of legal frameworks $\left(\chi^{2}(3), p<0.05\right)$ in the sustainability of fisheries in the two lakes (Table 4).

\section{DISCUSSION}

The main aim of the study was to identify and contextualise drivers and barriers to sustainability of small-scale fisheries in two peri-urban impoundments Chivero and Manyame in Zimbabwe. Three indicators: Fishery Performance Indicator (FPI), Community-Based Fishery Indicators (CFI) and FAO Small-Scale Fisheries Indicator (FSSFI) frameworks were used to evaluate the drivers and barriers affecting the sustainability of fisheries, and viability of fishing-dependent livelihoods in the two lakes.
Results of the study indicated the need for a consistent income, food security, and food nutrition as the main drivers of small-scale inland fisheries in Lakes Chivero and Manyame. Accessible fish markets and the educational levels of the fishers are also key drivers for the sustainability of small-scale inland fisheries in the two lakes. These findings resonate with research by Allison and Ellis (2001); Béné (2003) and FAO (2015), which reflect that small-scale inland fisheries serve multiple purposes, although food security, food nutrition and an income to alleviate poverty form the main basis for continued operations. The educational levels of fishers are key drivers of fisheries sustainability as they infer a capacity to: undergo fisheries and water resource conservation training, adopt new fishing methods and adapt to new post-harvest technologies (Fregene, 2002).

The three fisheries indicator assessment frameworks revealed almost similar ecological, economic, social and institutional barriers to the sustainability of the peri-urban fisheries in Lakes Chivero and Manyame. The FPI, in particular, indicated ecological barriers such as depleting fish stocks, water pollution, climate change and dynamics in land use patterns in the catchment as the main barriers to the sustainability of smallscale fisheries. The CFI indicated similar results with the FPI as it identified declines in targeted fish stocks and biodiversity as the key barriers to the sustainability of small-scale fisheries. The FSSFI indicated aquatic environmental degradation and practice of unsustainable fishing methods as the key ecological barriers to the sustainability of fisheries in Lakes Chivero and Manyame. The ecological barriers identified in this study resonate with generic ecological hazards threatening the sustainability of most marine, coastal and inland fisheries. Béné (2003); Béné et al. (2009); Allison et al. (2005, 2009); Marshall (2011); Kolding and Van Zwieten (2012); FAO $(2012,2016)$ largely attribute key ecological elements such as unfishable drawdown zones, depleting fish stocks and poor water quality and erratic water level fluctuations as barriers to the sustainability of inland fisheries in Benin, Chad, Cameroon, Zimbabwe, Niger and Malawi. For this study, the deteriorating water quality standards, declining fish stocks and biodiversity in the two peri-urban impoundments are owed to the transboundary (complex mixture of urban and rural characteristics) nature of the catchment areas, punctuated by a lack of clear demarcation and improper water and land resource governance (Nhapi and Gijzen, 2004; Khan et al., 2013).

The three indicator frameworks reflected economic barriers, such as poor post-harvest infrastructure, low recapitalisation and creditworthiness, volatile fish markets and subdued seasonal prices, as key threats to the sustainability of the fisheries in both lakes. Seasonal fluctuations in fish stocks tend to affect the fish prices at the fish markets in the two lakes, with prices relatively higher in the winter season (Seijo et al., 1998; FAO, 2015; Mhlanga and Mhlanga, 2013; Kupaza et al., 2015). The lack of efficient and climate-smart fishing and post-harvest technologies in small-scale inland fisheries affects fishing effort, fish catches and the subsequent market prices (Fregene, 2002). This economic barrier leads to price disparities in small-scale inland fisheries which tend to lead fishers to overexploit the fisheries resources using high fishing effort and inefficient gear (Béné, 2003; 2009).

The demographic distribution of the fishers showed male dominance in the two impoundments. All three fisheries assessment frameworks indicated social barriers such as disproportionate gender consideration, where females are marginalised and perform peripheral and fringe post-harvest roles, including fish gutting, gleaning, and cleaning in fisheries. 
Undefined and peripheral roles for women, even though they may be as educated as men in leadership positions, in the peri-urban fisheries ensures male domination of the industry (Matsue et al., 2014). The peri-urban nature of the two impoundments implies that women and the youths who are equally affected by poverty would have been attracted to fishing as an alternative source of income to alleviate poverty (Nelson et al., 2008; Khan et al., 2013; FAO, 2016). However, the FSSFI framework indicated a strict adherence to cultural values within the fishing communities, where some fisheries do not deliberately employ women for cultural, ethical and inferred hygienic reasons, which are largely mythical as stated by Allison et al. (2009) Béné (2009) and Matsue et al., (2014). This tends to marginalise women from lucrative fishing operations and economically disempowers them and discourages females from considering fishing as a career in both impoundments (Matsue et al., 2014).

From a governance and institutional perspective, the three frameworks showed that barriers such as restricted access to lucrative fishing zones, expensive annual fishing permits, low consideration for fisheries project management and extension services, fishing land access, rules, laws, and regulation awareness, as well as water conservation education and awareness, affect the sustainability of fisheries in both impoundments. Lack of transparency in fisheries operations is a highlighted barrier indicated by the FSSI, threatening the sustainability of small-scale inland fisheries. Lack of training and extension services may hinder adoption and transfer of fishing technologies to peri-urban fisherfolks and threatens the sustainability of individual small-scale inland fisheries (Adelekan and Fregene, 2015). Even more so, the peri-urban fisheries have poor social organisational networks, limited access to financial capital, rely on obsolete equipment and hardly have legal representation, and this threatens their sustainability (Béné, 2009). In most cases, institutional elements of fisheries are neglected and lead to their nonconsideration in economic planning and governance processes (Fregene, 2002; Béné, 2009, Welcomme et al., 2010; Bartley et al., 2015; Link et al., 2017; Stephen et al., 2018).

There are subtle differences in the key drivers and barriers reflected by the three indicator frameworks. This is because the three fisheries viability assessment frameworks lack conceptual coherence and often neglect to incorporate important aspects of the fishery system. In fact most fisheries sustainability assessment frameworks tend to consider individual fisheries, and are dimensional with much focus on fish stock assessment (Béné, 2009; Bartley et al., 2015), water and habitat dynamics (Marshall, 2011; Tendaupenyu, 2012, Nyarumbu and Magadza, 2016), impacts on fishing-dependent livelihoods (Garba, 1997; Allison et al., 2005; Salmi, 2005; Mhlanga and Mhlanga, 2013) or currently the effects of climate change (Brander, 2010; Welcomme et al., 2010; FAO, 2012; 2016; Wichelns, 2017). This suggests a need to assess fisheries sustainability using a bottom-up approach starting from individual fisheries < community fisheries < global/generic fisheries (Seijo et al., 1998; FAO, 2012; 2015). Inclusion of cultural, social, governance, ecological and economic aspects will lead to a holistic assessment of the sustainability of fisheries.

Comparative assessment of the perceptions of the fishers in Lakes Chivero and Manyame towards the drivers and barriers to the sustainability of fisheries reveal significant differences in perspectives towards drivers, such as the effect of educational levels, alternative income strategies adopted, food security of fishing livelihoods, and livestock owned. Some fishers consider the individuals' educational level to be irrelevant as a motivational factor driving fishing activities. Rather, fishing is viewed as a physical activity needing minimal cognitive effort. Fregene (2002) argues that such an attitude hinders the smooth operation and uptake of fisheries extension and management training services in most small-scale inland fisheries in SubSaharan Africa. Fishers from the two lakes differ significantly $(p<0.05)$ in their perspectives towards the need to earn an income from fishing being a driver of sustainability of fisheries. Rather, they relate the need to maximise profits with overexploitation and overfishing of the fisheries resources, often using unregulated gear in the two lakes. Thus, fishers in the two lakes tend to use illegal gear in order to maximise catches, resulting in overfishing which in the long-term threatens the sustainability of the fisheries and livelihoods of fishers themselves (see Tweddle et al., 2015; Irvine et al., 2018).

The significant differences in fishers' perceptions towards a need for food security as a driver of fisheries sustainability in the two lakes indicates that fishers have different motivational factors for continuing with fishing as a livelihood strategy. Fishers significantly disagree that owning livestock such as cattle and goats is a driver of fisheries sustainability in the two lakes. This partly reflects the periurban nature of the two lakes, and proximity of Lake Chivero to the main capital city of Harare, relative to Lake Manyame. Fishers in Lake Chivero adopt a more urban lifestyle and tend to alternatively go into non-fishing-related income activities such as trinket trading, tobacco marketing and formal jobs (FAO, 2013; Kupaza et al., 2015). Fishers in Lake Manyame adopt a more rural lifestyle with agriculture and livestock ranching as an alternative livelihood. Non-significant differences in perceptions towards most of the barriers to the sustainability of the fisheries between fishers in the two lakes indicated the universal nature of challenges facing smallscale inland fisheries, such as poor water quality and quantity (FAO, 2015), depleting fish stocks (Welcomme et al., 2010; Tweddle et al., 2015), climate change (Brander, 2010), gender disparity (Matsue et al., 2014), low capital and poor postharvest technology (Fregene, 2002) and peri-urbanisation (Khan et al., 2013; Nagendra and Ostrom, 2014).

\section{CONCLUSIONS AND RECOMMENDATIONS}

The main drivers for sustainability of fisheries include the need for a consistent income, food security and food nutrition in Lakes Chivero and Manyame. The applied fisheries sustainability assessment indices; the FPI, CFI and FSSFI, indicated similar barriers threatening the viability of the smallscale inland fisheries. However, the significant differences in the perceptions of small-scale inland fishers towards the barriers and drivers of fisheries between the two lakes shows the inherent uniqueness of individual fisheries and fishers. Thus, in order to guarantee the sustainability of the fisheries in the two peri-urban lakes, there is a need to consider a bottom-up approach incorporating the concerns of individual fisheries which then feeds into community fisheries and can inform global fisheries aspects. Even more so, future studies of fisheries may exploit the integrated application of a raft of fisheries assessment frameworks for effective evaluation of their sustainability in the face of ecological, economic, social and institutional threats. 


\section{ACKNOWLEDGEMENTS}

Our special thanks go to Mr Newman Songore at Lake Chivero Fisheries Research Station and all the Parks staff for assistance with the field logistics. We thank the Graduate Studies Office at Chinhoyi University of Technology for funding this research under Grant PG 4299. This research was also supported by funding from the Department for International Development (DFID) under the Climate Impact Research Capacity and Leadership Enhancement (CIRCLE) programme, implemented by the African Academy of Sciences (AAS) and the Association of Commonwealth Universities (ACU). We also thank the two anonymous reviewers who made this manuscript readable.

\section{REFERENCES}

ADELEKAN I and FREGENE T (2015) Vulnerability of artisanal fishing communities to flood risks in coastal southwest Nigeria. Clim. Dev. 7 (4) 322-338. https://doi.org/10.1080/17565529.2014.951011

AU-IBAR (African Union InterAfrican Bureau for Animal Resources) (2012) Regional assessment of fisheries issues, challenges and opportunities in Southern African region. Towards the formulation of the policy framework and reform strategy for fisheries and aquaculture in Africa. AU-IBAR, Nairobi.

ALLISON EH and HOREMANS B (2006) Putting the principles of the sustainable livelihoods approach into fisheries development policy and practice. Mar. Pol. 30 757-766. https://doi.org/10.1016/j. marpol.2006.02.001

ALLISON E and ELLIS F (2001) The livelihoods approach and management of small-scale fisheries. Mar. Pol. 25 377-388. https:// doi.org/10.1016/S0308-597X(01)00023-9

ALLISON E, ADGER N, BADJECK M, BROWN K, CONWAY D, DULVY N, HALLS A, PERRY A and REYNOLDS J (2005) Effects of climate change on the sustainability of capture and enhancement fisheries important to the poor: analysis of the vulnerability and adaptability of fisherfolk living in poverty. DFID Technical report. Project R4778J. DFID, Marine Resources Assessment Group, London, UK, $169 \mathrm{pp}$.

ALLISON EH, PERRY AL, BADJECK MC, ADGER WN, BROWN K, CONWAY D, HALLS AS, PILLING GM, REYNOLDS JD, ANDREW NL and DULVY N (2009) Vulnerability of national economies to the impacts of climate change on fisheries. Fish Fish. 10 173-196. https://doi.org/10.1111/j.1467-2979.2008.00310.x

ANDERSON JL, ANDERSON CM, CHU J, MERIDETH J, ASCHE F, SYLVIA G and VALDERRAMA D (2015) The fishery performance indicators. A management tool for triple bottom line outcomes, PLoS ONE 10 e0122809. https://doi.org/10.1371/journal. pone.0122809

BARTLEY DM, de GRAAF GJ, VALBO-JØRGENSEN J and MARMULLA G (2015) Inland capture fisheries: status and data issues. Fish. Manage. Ecol. 22 (1) 71-77. https://doi.org/10.1111/fme.12104

BÉNÉ C (2003) When fishery rhymes with poverty: a first step beyond the old paradigm on poverty in small-scale fisheries. World Dev. 31 (6) 949-975. https://doi.org/10.1016/S0305-750X(03)00045-7

BÉNÉ C, NEILAND AE, JOLLEY T, OVIE S, SULE O, LADU B, MINDJIMBA K, BELAL E, TIOTSOP F, BABA M, DARA L, ZAKARA A and QUENSIERE J (2003) Inland fisheries, poverty and rural livelihoods in the Lake Chad Basin. J. As. Afr. Stud. 38 (1) 17-51. https://doi.org/10.1177/002190960303800102

BÉNÉ C (2009) Are fishers poor or vulnerable? Assessing economic vulnerability in small- scale fishing communities. J. Dev. Stud. 45 (6) 911-933. https://doi.org/10.1080/00220380902807395

BÉNÉ C, STEEL E, KAMBALA LUADIA B and GORDON A (2009) Fish as the bank in the water-evidence from chronic-poor communities in Congo. Food Policy 34 104-118. https://doi. org/10.1016/j.foodpol.2008.07.001

BOYD H and CHARLES A (2006) Creating community based indicators to monitor sustainability of local fisheries. Ocean Coast. Manage. 49 237-258. https://doi.org/10.1016/j. ocecoaman.2006.03.006
BRANDER K (2010) Impacts of climate change on fisheries. J. Mar. Syst. 79 389-402. https://doi.org/10.1016/j.jmarsys.2008.12.015

CHU J, GARLOCK T, ASCHE F and ANDERSON JL (2017) Impact evaluation of a fisheries development project. Mar. Pol. 85 141-149. https://doi.org/10.1016/j.marpol.2017.08.024

COOKE SJ, PAUKERT C and HOGAN Z (2012) Endangered river fish: factors hindering conservation and restoration. Endanger. Species Res.17 179-191. https://doi.org/10.3354/esr00426

COOKE SJ, LAPOINTE NWR, MARTINS EG, THIEM JD, RABY GD, TAYLOR MK, BEARD TDJR and COWX IG (2013) Failure to engage the public in issues related to inland fishes and fisheries: strategies for building public and political will to promote meaningful conservation. J. Fish Biol. 83 (4) 997-1018. https://doi. org/10.1111/jfb.12222

DE GRAAF G and GARIBALDI L (2014) The value of African fisheries. FAO Fisheries and Aquaculture Circular 109376

SEIJO JC, DEFEO O and SALAS S (1998) Fisheries bio-economics theory: modelling and management. FAO Fisheries Technical Paper. Food and Agriculture Organization of the United Nations, Rome. 368 pp.

FAO (2012) The State of World Fisheries and Aquaculture 2012. Food and Agriculture Organisation, Rome. 209 pp.

FAO (2013) Statistics. Capture production 1950-2011. URL: http:// www.fao.org/fishery/statistics/en (Accessed 13 February 2017).

FAO (2014) The State of World Fisheries and Aquaculture 2014. Food and Agriculture Organisation of the United Nations, Rome. 223 pp.

FAO (2014a) CWP Handbook of Fishery Statistical Standards. Section G: Fishing Areas - General. Rome, Italy.

FAO (2014b) The State of World Fisheries and Aquaculture - 2014 (SOFIA). Rome, Italy.

FAO (2014c) The Water-Energy-Food Nexus: A New Approach in Support of Food Security and Sustainable Agriculture. Food and Agriculture Organisation of the United Nations, Rome.

FAO (2015) Voluntary guidelines for securing sustainable small-scale fisheries. URL: http://www.fao.org/policy-support/resources/ resources-details/en/c/418453/ (Accessed 24 March 2017).

FAO (2016) The State of World Fisheries and Aquaculture 2016. Food and Agriculture Organisation of the United Nations, Rome. 200 pp.

FREGENE BT (2002) Poverty assessment of fishing communities of Lagos State, Nigeria. PhD thesis, University of Ibadan, Nigeria.

GARCIA SM and ROSENBERG AA (2010) Food security and marine capture fisheries: characteristics, trends, drivers and future perspectives. Philos. Trans. R. Soc. B 365 (1554). https://doi. $\operatorname{org} / 10.1098 /$ rstb.2010.0171

GARBA AR (1997) The importance of nomadic education in Nigeria. New Nigeria September 1997. 16 pp.

GILLETT R (2009) Fisheries in the Economies of Pacific Island Countries and Territories.: Asian Development Bank, Mandaluyong City, Philippines. 484 pp.

HOWELLS MS, HERMANN M, WELSCH M, BAZILIAN R, SEGERSTRÖM R, ALFSTAD D, GIELEN H, ROGNER G, FISCHER H, VAN VELTHUIZEN D and co-authors (2013) Integrated analysis of climate change, land-use, energy and water strategies. Nat. Clim. Change 3 621-626. https://doi.org/10.1038/ nclimate1789

KÉBÉ M and TALLEC F (2006) Contribution of fisheries sector to national economies (West and Central Africa). Sustainable Fisheries Livelihoods Programme (SFLP) in West Africa. Impression AGCom, Cotonou, Benin.

KHAN MSA, PRAKASH A, NARAIN V and SADA R (2013) Adapting to peri-urban water insecurity induced by urbanization and climate change: insights from South Asia. Proceedings of the Resilient Cities 2013 Congress, 31 May-2 June Bonn, Germany.

KOLDING J and VAN ZWITTEN PAM (2012) Relative lake level fluctuations and their influence on productivity and resilience in tropical lakes and reservoirs. Fish. Res. (115-116) 99-109. https:// doi.org/10.1016/j.fishres.2011.11.008

IRVINE K, ETIEGNI CA and WEYL OLF (2018) Prognosis for long term sustainable fisheries in the African Great Lakes. Fish. Manage. Ecol. 00 1-13. https://doi.org/10.1111/fme.12282

LINK JS, THÉBAUD O, SMITH DC, SMITH ADM, SCHMIDT J, RICE J, POOS JJ, PITA C, LIPTON D, KRAAN M and co-authors 
(2017) Keeping humans in the ecosystem. ICES J. Mar. Sci. 74 1947-1956. https://doi.org/10.1093/icesjms/fsx130

MAGADZA CHD (2003) Lake Chivero: A management case study. Lakes Reserv. Res. Manage. 8 69-81. https://doi.org/10.1 046/j.1320-5331.2003.00214.xMARSHALL BE (2011) Fishes of Zimbabwe and their Biology. Smithiana Monograph 3. The Southern African Institute for Aquatic Biodiversity, Grahamstown.

NAGENDRA H and OSTROM E (2014) Applying the social-ecological system framework to the diagnosis of urban lake commons in Bangalore, India. Ecol. Soc. 19 (2) 67-72. https://doi.org/10.5751/ ES-06582-190267

NELSON R, HOWDEN SM and STAFFORD SMITH M (2008) Using adaptive governance to rethink the way science supports Australian drought policy. Environ. Sci. Polic. 11 588-601. https:// doi.org/10.1016/j.envsci.2008.06.005

NHAPI I and GIJZEN HJ (2004) Wastewater management in Zimbabwe in the context of sustainability, Water Polic. J. 6 (6) 115-121. https://doi.org/10.2166/wp.2004.0033

NHIWATIWA T, BARSON M, HARRISON AP, UTETE B and COOPER RG (2011) Metal concentrations in sharptooth catfish (Clarias gariepinus, Burchell 1822), sediments and water in periurban rivers in Zimbabwe. Afr. J. Aquat. Sci. 3 243-252. https://doi. org/10.2989/16085914.2011.636906

NYARUMBU TO and MAGADZA CHD (2016) Using the Planning and Management Models of Lakes and Reservoirs (PAMOLARE) as a tool for planning the rehabilitation of Lake Chivero, Zimbabwe. Environ. Nano. Monit. Manage. 5 1-12. https://doi.org/10.1016/j. enmm.2015.10.002

STEPHENSON RL, PAUL S, WIBER M, ANGEL E, BENSON AJ, CHARLES A, CHOUINARD O, CLEMENS M, EDWARDS D, FOLEY P and co-authors (2018) Evaluating and implementing social-ecological systems: A comprehensive approach to sustainable fisheries. Fish Fish. 19 (5) 853-873. https://doi. org/10.1111/faf.12296
TAYLOR WW, LEONARD NJ, KRATZER JF, GODDARD C and STEWART P (2007) Globalization: implications for fish, fisheries and their management. In: Taylor WW, Schechter MG and Wolfson LG (eds) Globalization: Effects on Fisheries Resources. Cambridge University Press, Cambridge, UK. 21-46 pp. https://doi.org/10.1017/ CBO9780511542183.005

TENDAUPENYU P (2012) Nutrient limitation of phytoplankton in five impoundments on the Manyame River, Zimbabwe. Water SA 38 (1) 97-104. https://doi.org/10.4314/wsa.v38i1.12

TWEDDLE D, COWX IG, PEEL R and WEYL OLF (2015) Challenges in fisheries management in the Zambezi, one of the great rivers of Africa. Fish. Manage. Ecol. 22 99-111. https://doi.org/10.1111/fme.12107

UTETE, B, PHIRI C, MLAMBO SS, MUBOKO N and FREGENE BT (2018) Fish catches, and the influence of climatic and non-climatic factors in Lakes Chivero and Manyame, Zimbabwe. Cogent Food Agric. 4 (1) https://doi.org/10.1080/23311932.2018.1435018

VÖRÖSMARTY CJ, MCINTYRE PB, GESSNER MO, DUDGEON D, PRUSEVICH A, GREEN P and GLIDDEN S (2010) Global threats to human water security and river biodiversity. Nature 467 (7315) 555-561. https://doi.org/10.1038/nature09440

WELCOMME RL, COWX IG, COATES D, BÉNÉ C, FUNGE-SMITH S, HALLS A and LORENZEN K (2010) Inland capture fisheries. Phil. Trans. of the Royal Soc. of Biol. 365 2881-2896. https://doi. org/10.1098/rstb.2010.0168

WEPENER W, VAN VUREN JHJ and DU PREEZ HH (2001) Uptake and Distribution of a copper, iron and zinc mixture in gill, live rand plasma of a freshwater teleost, Tilapia sparmanii. Water SA 27 (1) 99-108. https://doi.org/10.4314/wsa.v27i1.5016

WICHELNS D (2017) The water-energy-food nexus: Is the increasing attention warranted, from either a research or policy perspective? Environ. Sci. \& Pol. 69 113-123. https://doi.org/10.1016/j. envsci.2016.12.018

WorldFish Center (2009) Fish and aquaculture in a changing climate. Proceedings from the UNFCCC COP-15, December 2009, Copenhagen. 